|Araştırma Makalesi / Research Article|

\title{
Öz Düzenleme Becerilerinin İlkokula Hazırbulunuşluk Üzerindeki Etkisi
}

\section{The Impact Of Self-Regulation Skills On School Readiness}

\section{Hilmi Tekin ${ }^{1}$, Sezai Koçyiğit ${ }^{2}$}

\author{
Anahtar Kelimeler \\ erken çocukluk \\ okula hazırbulunuşluk \\ öz düzenleme
}

\section{Keywords \\ early childhood \\ school readiness \\ self-regulation}

Başvuru Tarihi/Received

17.09.2019

Kabul Tarihi /Accepted

16.07.2020
Öz

Bu araştırma, öz düzenleme becerilerinin ilkokula hazırbulunuşluk üzerindeki etkisini incelemek amacıyla yapılmıştır Araştırmanın evrenini, 2016-2017 eğitim-öğretim yılında Muğla ili Menteşe ilçe merkezinde, Millî Eğitim Bakanlığı'na bağlı okul öncesi eğitim kurumlarına devam etmekte olan, normal gelişim gösteren ve bir sonraki eğitim öğretim yılında ilkokula başlayacak çocuklar oluşturmaktadır. Araştırmanın örneklemine iki özel anaokulu, iki resmi anaokulu ve üç ilkokula bağlı anasınıfına devam eden ve bir sonraki eğitim öğretim yılında ilkokula başlayacak olan 255 çocuk dâhil edilmiştir. Araştırmada ilişkisel tarama modeli kullanılmıştır. Araştırmada, Smith-Donald ve arkadaşları (2007) tarafından geliştirilen ve Fındık Tanrıbuyurdu (2012) tarafından Türkçe-ye uyarlanan “Okul Öncesi Öz Düzenleme Ölçeği (PSRA)” ve G.H. Hiltreth ve arkadaşları (1949) tarafından geliştirilen ve Oktay (1980) tarafından Türkçeye uyarlanması yapılan Metropolitan Okula Hazırbulunuşluk Testi (Metropolitan Readiness Test) kullanılmıştır. Verilerin analizinde, SPSS 22.0 paket programı kullanılmıştır. Puan türlerinin normallik testleri sonucunda normal dağılım gösterdikleri tespit edildiğinden iki gruplu karşılaştırmalarda bağımsız grup t-testi, üç ve daha fazla gruplu karşılaştırmalarda ise anova testi kullanılmıştır. Bağımlı ve bağımsız değişkenler arasındaki ilişkiyi incelemek için basit doğrusal regresyon, ölçeklerin alt boyutları arası ilişkileri incelemek için ise Pearson momentler çarpımı korelasyonu kullanılmıştır. Anlamlılık seviyesi 0,05 olarak belirlenmiştir. Araştırma sonucunda; öz düzenleme becerileri ile ilkokula hazırbulunuşluk arasında pozitif yönde anlamlı bir ilişki bulunmuştur.

\section{Abstract}

This study was conducted to examine the impact of self-regulation skills on primary school readiness. The research population consisted of children who were attending preschool education institutions under the Ministry of National Education in Menteşe district of Muğla province during the 2016-2017 academic year, undergoing normal development and would attend primary school in the next academic year. The research sample contained 255 children who were at-tending two private kindergartens, two public kindergartens and three kindergartens affiliated with primary school, and would go to primary school in the next academic year. The study employed relational survey model. In the study, "Pre-School Self-Regulation Assessment (PSRA)" that was devel-oped by Smith-Donald et al. (2007) and adapted to Turkish by Fındık Tanrıbuyurdu (2012), and Metropolitan Readiness Test that was developed by G.H. Hiltreth et al. (1949) and adapted to Turkish by Oktay (1980) were administered. The data was analyzed using SPSS 22.0 package program. As normality tests indicated that scoring types showed normal distribution, we performed independent group t-test for com-parisons with two groups, and ANOVA test for comparisons involving three or more groups. The study used simple linear regression to analyze the relationship between dependent and independent variables, and Pearson's moment correlation coefficient to analyze relationships between the subscales. The significance level was set at 0.05 . The results of the study revealed a positive significant relationship between self-regulation skills and school readiness.

\footnotetext{
${ }^{1}$ Sorumlu Yazar, Muğla Sıtkı Koçman Üniversitesi, Muğla Meslek Yüksekokulu, Çocuk Bakımı ve Gençlik Hizmetleri Bölümü, Muğla, TÜRKiYE; https://orcid.org/ 0000-0002-2324-6631

${ }^{2}$ Aydın Adnan Menderes Üniversitesi, Eğitim Fakültesi, Okul Öncesi Eğitimi Bilim Dalı, Aydın, TÜRKiYE; https://orcid.org/ 0000-0003-0101-7683
}

Alıntı/Citation: Tekin, H., \& Koçyiğit, S. (2020). Öz düzenleme becerilerinin ilkokula hazırbulunuşluk üzerindeki etkisi. Kastamonu Education Journal, 28(5), 19321945. doi: 10.24106/kefdergi.3928 


\section{Extended Abstract}

\section{Introduction}

One important purpose of the preschool educational process, in which children participate beginning from the 36th month, is to ensure children's bodily, mental and emotional development, their acquiring good habits and preparing them for primary school in this direction. (MEB, 2013, s. 10). According to Boyd vd. (2005), children need cognitive, social and motivational skills for achieving success in school. These skills cover situations such as comprehending others' emotions, understanding directives, focusing attention, controlling self emotions and behaviors, ability to regulate social interactions with relatives and the ability to cooperate (Fındık Tanrıbuyurdu, 2012: 27). These skills are called "self-regulation skills". Self-regulation skills appear as one senior level skill that predict the readiness for school (Eisenberg vd., 2010, s. 681). A longitudinal regulation made on five year age group children showed that self-regulation skills predict the reading-writing and mathematic skills measured at age six (Blair and Razza, 2007, s. 647).

\section{Method}

The purpose of this research is to examine the impact of self-regulation skills on the level of readiness for primary school. The scope of research is comprised of children, who, during the educational year of 2016-2017, were continuing preschool educational institutions affiliated with the Ministry of National Education in the City of Muğla, Province of Menteşe, the Central District , who manifest normal development and who will commence primary school in the following year. On the other hand, the sampling scope of the research included 255 children, who attend two private kindergartens, two public kindergartens and nursery classes of three primary schools and who will commence primary school in the upcoming educational year. The research has used a relational scanning model. Again in this research, we have used he "Preschool Self-Regulation Assessment (PSRA), which was developed by Smith-Donald colleagues (2007) and which was translated into Turkish by Fındık Tanrıbuyurdu (2012), as well as the Metropolitan School Readiness Test (Metropolitan Readiness Test), which was developed by G.H. Hiltreth and colleagues (1949) and which was translated into Turkish by Oktay (1980). The SPSS 22.0 package software was used for analyzing data. As it was determined that point types showed a normal distribution pursuant to normality test, the t-test was used in two-group comparisons and the anova test was used during comparisons with three or more groups. Linear regression was used for examining the relation between de-pendent $\&$ independent variables and the Pearson product-moment correlation coefficient was used for examining the relations between the sub-dimensions of scales. The meaningfulness was established to be 0.05 .

\section{Result and Discussion}

The research concluded a positive meaningful relation between self-regulation skills and readiness to primary school. The fact that the relation between the self-regulation skills and readiness to primary school is meaningful and positive can be interpreted to the effect that children with high self-regulation skills can be more ready for school in social, emotional and cognitive terms. This finding is further supported by the fact that the research, which was conducted by Akawi (2011) on preschool children that are included in the Head Start program, established a positive \& meaningful relation between children's self-regulation skills and their school readiness levels.

The research has also examined the relations between the sub-dimensions of the Metropolitan School Readiness Scale and the Preschool Self-Regulation Scale. When the presence of a relation was examined between the total points of Metropolitan Primary School Readiness Scale and sub-dimension points the Preschool Self-Regulation Scale, a high-level meaningful positive relation was identified between the attention-impulse control sub-dimension points of children in the early-childhood period and their pri-mary school readiness points, and a medium-level meaningful positive relation was identified between their positive emotion sub-dimension points and their primary school readiness points. Accordingly, one can say that children with high attention-impulse levels have a high level of primary school readiness, and have medium-level positive emotion levels. In other words, one can say that children have an increased level of primary school readiness if they can control their attentions and impulses better and if they can develop more positive emotions. When the presence of a relation was examined between the total points of the Preschool Self-Regulation Scale and the sub-dimension points of the Primary School Readiness Scale, a high-level positive relation was identified between the self-regulation general points of children and their reading-readiness sub-dimension points, which stood at a medium-level for their number-readiness sub-dimension points and at a low level for their copying subdimension points. Accordingly, one can state that children with high levels of self-regulation skills have a high reading-readiness level, a medium number-readiness level and a low copying skill level. In other words, one can say that when children in the earlychildhood period have increased levels of self-regulation skills, they become more ready for learning reading \& number skills and improving their copying skills. 


\section{GíRiş}

Okul öncesi dönemde çocuklar dürtü, duygu ve düşüncelerini kontrol etmek için zihinsel stratejiler kullanmaya, sosyal ve ahlaki değerlere göre hareket etmeye, kendi belirledikleri hedefler ve diğerlerinin beklentilerini karşılayacak şekilde kendi düşünce ve davranışlarını yönlendirmeye başlarlar. Okul öncesi dönemde kazanılması hedeflenen bu becerilerin tümü tek bir kavram ile öz düzenleme becerileri olarak adlandırılmaktadır (Bayındır ve Ural, 2016, s. 121).

Öz düzenleme genel olarak bireyin düşüncelerini, duygularını, dürtülerini, dikkatini ve davranışlarını kontrol etmesi ve düzenlemesi olarak tanımlanmaktadır (Zimmerman, 2000, s. 14). Ayrıca öz düzenleme bir termostata benzetilmiştir. Termostatın, belirli bir sıcaklığı takip ederek oda sıcaklığını belirlenen sıcaklıkta tutmak için odayı soğutma veya ısıtmayı sağlayacak şekilde çalışması ya da durması ile öz düzenleme arasında bir benzerlik olduğunu ifade edilmiştir. Bu açıdan bakıldığında bireyin öz düzenleme becerileri ile çevre arasında bir bağlantı vardır. Bireyin öz düzenleme becerileri çevreyi değiştirirken, çevre de bireyin öz düzenleme sisteminin gelişimine katkı sağlar (Can Aran, 2015, s. 208).

Öz düzenlemenin alt boyutlarıyla ilişkin birçok farklı görüş bulunmaktadır. Bunun, kuramsal alt yapıların farklılı̆̆ından kaynaklandığı söylenebilir. Geçerlik, güvenirlik ve Türkiye'deki çocuklar için uyarlama çalışması Fındık Tanrıbuyurdu (2012) tarafından yapılan Okul Öncesi Öz Düzenleme Ölçeği'nin kuramsal çerçevesinde öz düzenleme kavramı, dikkat, duygu ve davranış düzenleme alt boyutlarında değerlendirilmiştir. Dolayısıyla Türk kültürüne uyarlanan ölçeğin kuramsal çerçevesine sadık kalmak adına öz düzenleme kavramı, dikkat, duygu ve davranış düzenleme olarak üç alt boyutta açıklanmıştır.

Dikkati düzenleme, bilişsel işlevlerin bir parçasıdır (Bronson, 2000, s. 58). Dikkatin bir uyarana odaklanması ve ihtiyaç duyulduğunda yön değiştirmesi gibi üst düzey dikkat becerileri "çaba gerektiren kontrol" ile ilişkilidir ve bu beceriler yürütücü dikkat olarak adlandırımaktadır. Çaba gerektiren kontrolün bir bölümünü de yürütücü dikkat oluşturur (Eisenberg vd., 2011, s. 78). Çaba gerektiren kontrol, dikkati düzenleme sürecinde bireyin ilgisini çeken uyarana yönelmek istemesine rağmen amaca yönelik uyarana odaklanabilmesine ve dikkati sürdürebilmesine imkân sağlar. Birey bu süreçlerin sonunda yine istemli olarak uygun davranışı yerine getirir ve uygun olmayan davranışı engeller (Eisenberg ve Spinrad, 2004, s. 337).

Duygu düzenleme, beyinde bulunan orbitofrontal korteksin görevlerinden biri olarak kabul edilir ve genel anlamıla yeni bir duygusal tepkinin başlatılmasını ya da devam eden duygusal tepkilerin değiştirilmesini içerir (Ochsner ve Gross, 2005, s. 244). Duygu düzenleme süreci otomatik ya da kontrollü olabilmektedir (Gross, 1999; Akt. Şahin ve Arı, 2016, s. 3). Bir stresle karşılaşılması durumunda fizyolojik olarak yüksek kan basıncı, hızlı bir nabız, nefes alışverişlerinin artması, terleme gibi otomatik tepkilerin yanında vurma, ağlama, çığlık atma veya geri çekilme gibi davranışsal tepkiler de verilebilmektedir. Ayrıca duygular seçici dikkat süreçleri, hafıza bozuklukları, yalanlama, öngörme ya da kişinin kendini suçlaması, başkalarını suçlaması, uzun uzadıya düşünmesi veya olumsuz yönde düşünmesi gibi daha bilinçli bilişsel süreçler tarafından düzenlenebilmektedir (Garnefski vd., 2001, s. 1312). Duygular, bir uyaran karşısında, bireyin genel eğilimine bağlı olarak onu aniden ve hızlıca karar verip eylemde bulunmaya iter. Bu durumda duygular, dikkati de içeren bilişsel süreçlerde "düzenleyici" olarak görev alır. Öz düzenlemenin bilişsel boyutuna işaret eden yürütücü işlevler de bir anlamda duygu düzenleme sürecine bağlıdır (Fındık Tanrıbuyurdu, 2012, s. 12).

Davranışı düzenleme, çocukların davranışlarını gerçekleştirmeden önce planlaması, tepkilerini kontrol etmesi, sabır gösterebilmesi, dürtüsel davranmaması ve sırasını bekleyebilmesi gibi durumlarla açıklanabilir (Smith-Donald vd., 2007, s.174). Davranışı düzenleme dikkate odaklanma, çalışma belleği ve baskılayıcı kontrol de dahil olmak üzere yürütücü işlev becerilerinin bir belirtisi anlamına gelir (Tilbe, 2015, s. 6). Davranış düzenleme, çaba gerektiren kontrol kavramıyla oldukça ilişkilidir. Bilerek ve farkında olarak dikkatin ve davranışın engellenmesi, değiştirilmesi, aktive ya da pasifize edilmesi becerileri çaba gerektiren kontrol olarak isimlendirilir (Eisenberg vd., 2011, s. 78). Çaba gerektiren kontrol seviyeleri yüksek çocuklar, duyguları ve dikkatlerini kontrol edebildikleri kadar davranışların da kontrol altına alabilirler (Carlson ve Wang, 2007, s. 491).

Okul öncesi dönem boyunca çocukların gerçekleştirmesi gereken birçok gelişim görevi vardır. Bunlar arasında topluma uyum sağlama, verilen yönergeleri anlama, kendi istek ve ihtiyaçları ile toplumun istek ve ihtiyaçları arasında denge kurma ve akademik becerilerini geliştirme görevleri yer almaktadır. Bu gelişim görevlerinin gerçekleştirilmesine etki eden en önemli becerilerden biri öz düzenleme becerileridir (Vohs ve Baumeister, 2011, s. 265). Çocukların öz düzenleme becerileri gelişiminin desteklenmesi, aynı zamanda onların sosyal, duygusal beceriler ile akademik becerilerini de desteklemek anlamına gelmektedir. Okul öncesi dönemde sosyal, duygusal ve akademik beceriler yönünden desteklenen çocuklar, okula hazırbulunuşluklarını tamamlayabilmektedirler. Okula hazırbulunuşluk, okul yeterliliğini belirlemek amacıyla geniş ölçekte kullanılan bir terimdir, ancak araştırmacılar arasında çocuk için okula hazırbulunuşluk kavramını tanımlayan veya bu yetkinliği elde etmek için en iyi yolu açıklayan bir fikir birliği yoktur (Magdalena, 2014, s.734). "Hazırbulunuşluk” terimi ilk kez 1899'da Patrick tarafından kullanılmıştır. Patrick öğrenmede, bilişsel gelişimde olgunluktan ve çocukların fiziksel olarak olgunlaşmasından bahseder ve bazı çocukların okuma için gerekli mental olgunluğa yedi yaşında erişirken bazılarının erişemeyebileceğini belirtir (Mason ve Sinha, 1992, s. 8). Okul olgunluğu ve okula hazırbulunuşluk kavramı ilk defa "Amerikan Küçük Çocukların Eğitimi Ulusal Birliği” (NAEYC) tarafından 1964 yılında ortaya atılmış ve "bir çocuğun okula başlamadan önceki zamanda kazandığı becerilerin tamamı" olarak ifade edilmiştir (Skeete, 2006; Akt. Koçyiğit, 2009, s. 7). Yıllardır okula başlamaya ve okuma yazmaya hazırlık olarak açıklanan hazırbulunuşluk kavramı günümüzde "öğrenmeye hazır olma" şeklinde ifade edilmektedir (Oktay, 2013, s. 75). Hazırbulunuşluk düzeyinin tespit edilmesi, okulun ilk günlerinden itibaren çocuğun okul yaşamına yönelik kişisel özelliklerine uygun olarak, ona rehberlik yapılmasını sağlar. Çocuğu doğru anlamda yönlendiren bir rehberlik pogramı ile çocuk geleceğini planlama ve programlama açısından bilgi ve beceriler ile donanmış olur (Yapıcı, 2004, s. 4). Boyd vd.'ne (2005) göre çocukların okulda başarılı olabilmeleri için bilişsel, sosyal ve 
motivasyonel becerilere ihtiyaçları vardır. Bu beceriler, başkalarının duygularını kavrama, yönergeleri anlama ve dikkatini odaklama, kendi duygu ve davranışlarını kontrol etme, akranlarıyla olan sosyal etkileşimlerini düzenleyebilme ve işbirliği yapabilme gibi durumları kapsar (Fındık Tanrıbuyurdu, 2012, s. 27).

Öz düzenleme becerileri, okula hazırbulunuşluğu yordayan üst düzey becerilerden biri olarak karşımıza çıkmaktadır (Eisenberg vd., 2010, s. 681). Beş yaş grubu çocuklarla yapılan boylamsal bir araştırma, öz düzenleme becerilerinin, altı yaşta ölçülen okumayazma ve matematik becerilerini yordadığını ortaya koymuştur (Blair ve Razza, 2007, s. 647). Çocukların ilköğretime hazırbulunuşluk düzeylerinde sosyal ve duygusal beceriler önemli bir rol üstlenir. Öz düzenleme ve çocukların sosyal becerileri arasında pozitif ilişkiler olduğunu gösteren çalışmalar vardır. Duygu düzenlemenin de temelinde yer alan çocukların duygularının farkında olmaları ve çevreden gelen duygusal sinyalleri doğru algılıyor olmaları, daha sonraki akademik başarı ve sosyal becerileri üzerinde olumlu etkilere sahiptir (Izard vd., 2001, s. 18).

Çocukların çaba gerektiren kontrollerinin, okuma, matematik ve dilbilimi becerilerindeki ölçüler de dahil, akademik becerileri veya okul başarıları ile pozitif ilişkili olduğu yönünde gittikçe artan kanıtlar mevcuttur (Fabes, Martin, Hanish, Anders, \& MaddenDerdich, 2003; NICHD Erken Çocukluk Bakım Araştırma Ağı, 2003; Valiente, Lemery-Chalfant, \& Castro, 2007; Akt. Eisenberg vd., 2010, s. 683). Erken çocukluk dönemi üzerine çalışan araştırmacılar da öz düzenlemenin okul hazırbulunuşluğu ve başarısına etkisi üzerinde durmuşlardır (Mccelland ve Tominey, 2011, s. 355). İyi bir öz düzenleme becerisi, çocuk için okula hazır olma yönünden ciddi derecede bir avantaj sağlamaktadır. Nitelikli öğrenmeye ve sosyal etkileşime yardımcı olan öz düzenleme, beraberinde akademik başarıyı getirmektedir (Montroy vd., 2014, s. 307).

Alan yazın incelendiğinde, yurtdışında ve Türkiye'de okul öncesi dönemde öz düzenleme becerileri ile okula hazırbulunuşluk kavramı arasındaki ilişkiye yönelik çalışmaların hız kazanmaya başladığı ancak Türkiye'de henüz bu konuda bir çalışmanın olmadığı görülmektedir (Akawi, 2011; Riva Ryan, 2015; Blair ve Razza, 2007; Blair ve Raver, 2015; Sektnan vd. 2010; Eisenberg Valiente ve Eggum, 2010; Mccelland ve Tominey, 2011; Torres, 2011; Molnar, 2016; Willis ve Laura, 2013). Bununla birlikte, Türkiye'de okul öncesi dönemde öz düzenleme becerilerine yönelik ölçek uyarlama ve geliştirme çalışmaları yapılmıştır. Okul öncesi eğitimi alanında farklı yaş gruplarındaki çocukların öz düzenleme becerilerini içeren çalışmaların sayısının da gün geçtikçe artmakta olduğu görülmektedir (Aydın, 2018; Öztabak, 2017; Aydın ve Ulutaş, 2017; Bayındır ve Ural, 2016; Eke, 2017; Ertürk Kara ve Gönen, 2015; Tozduman Yaralı ve Güngör Aytar, 2017; Ertürk, 2013; Yıldız vd., 2014; Keleş, 2014; Fındık Tanrıbuyurdu, 2012). Okul öncesi dönem çocuklarının öz düzenleme becerileri ile ilkokula hazırbulunuşlukları arasındaki ilişki üzerine bir çalışmanın yapılmamış olması, öz düzenleme becerilerinin çocuğun ilkokula hazırbulunuşluğuna ne düzeyde katkıda bulunduğunun ortaya konulması açısından literatüre önemli bir katkı sağlayabilir.

Alan yazında yer alan bilgilerden yola çıkarak bu araştırmada, çocukların öz düzenleme becerileri ve ilkokula hazırbulunuşlukları konusu ele alınmıştır. Öz düzenleme becerileri çocukların bilişsel, sosyal ve duygusal gelişimleri ile ilişkilidir. Çocuğun bilişsel gelişimi, onun dikkat ve dürtü kontrolü becerisini destekler. Sosyal ve duygusal gelişimi ise onun dürtülerini ve duygularını kontrol etmesine yardımcı olur. Dikkat ve dürtülerini kontrol edebilen ve olumlu duygular geliştirebilen çocuklar ilkokula daha kolay uyum sağlayabilmekte, okulun gerektirdiği sorumlulukları zorlanmadan yerine getirebilmektedir. illkokula rahat bir şekilde uyum sağlayan çocuklar ise ileri dönemlerde karşısına çıkan akademik ve sosyal sorunlarla baş etmede zorluk yaşamayacaktır. Bu bağlamda çocukların öz düzenleme becerileri ile ilkokula hazırbulunuşlukları arasındaki ilişkinin belirlenmesinin, öz düzenleme becerilerinin ilkokula hazırbulunuşluğuna etkisini ortaya koymak, öz düzenleme becerilerinin nasıl geliştiği ve hangi etkenlerin bu gelişim sürecinde etkili olduğuna yönelik çalışmalara katkıda bulunması açılarından önemli olduğu düşünülmüştür. Aynı zamanda çalışmanın, okul öncesi eğitim alanındaki paydaşlara çocukların ilkokula hazırbulunuşluğuna etki eden ve çocuklara erken çocukluk döneminde kazandırılması gereken sosyal, bilişsel ve motivasyonel becerilerin neler olduğu konusunda rehberlik edeceği; alan yazına katkı sağlayacağı ve konuyla ilgili çalışmalara rehberlik edeceği öngörülmektedir.

\section{Amaç}

Araştırmanın temel amacını, öz düzenleme becerilerinin ilkokula hazırbulunuşluk üzerindeki etkisinin incelenmesi oluşturmaktadır. Bu temel amaç doğrultusunda aşağıdaki sorulara yanıt aranmıştır.

1. Okul öncesi öz düzenleme ölçeği ve alt boyutları (dikkat-dürtü kontrolü ve olumlu duygu) ile metropolitan ilkokula hazırbulunuşluk ölçeği ve alt boyutları (okuma hazırlığı, sayı hazırlığı ve kopya etme becerisi) arasında anlamlı bir ilişki var midır?

2. Erken çocukluk dönemi çocuklarının öz düzenleme becerileri ilkokula hazırbulunuşluğu yordamakta mıdır?

3. Okul öncesi öz düzenleme ölçeği puanları çocukların cinsiyeti, herhangi bir okul öncesi kuruma devam etme süresi, ailedeki çocuk sayısı, anne-babaların yaş, öğrenim ve çalışma durumu değişkenlerine göre farklılaşmakta mıdır?

4. Metropolitan okula hazırbulunuşluk ölçeği puanları çocukların cinsiyeti, herhangi bir okul öncesi kuruma devam etme süresi, ailedeki çocuk sayısı, anne-babaların yaş, öğrenim ve çalışma durumu değiş̧enlerine göre farklılaşmakta mıdır?

\section{Varsayımlar}

Araştırmaya ilişkin varsayımlar aşağıda sunulmuştur;

1. Araştırmaya dâhil edilen çocukların ailelerine ilişkin demografik verilerin elde edildiği gelişim dosyalarındaki bilgilerin doğru olduğu varsayılmıştır. 
2. Evrenden seçilen örneklem grubunun temsil niteliğine sahip olduğu varsayılmıştır.

\section{Kapsam ve Sınırlılıklar}

Araştırma, 2016-2017 eğitim-öğretim yılında Muğla ili Menteşe ilçe merkezinde Millî Eğitim Bakanlığına bağlı olarak hizmet veren iki özel anaokulu, iki resmi anaokulu ve üç ilkokula bağlı anasınıfına devam eden ve bir sonraki eğitim öğretim yılında ilkokula başlayacak olan 255 çocuk ile sınırlandırılmıştır.

\section{YÖNTEM}

\section{Araștırmanın Modeli}

Öz düzenleme becerilerinin ilkokula hazırbulunuşluk üzerindeki etkisinin incelendiği bu araştırma, ilişkisel tarama modelindedir. Tarama modellerinden ilişkisel tarama modelinde, iki ve daha çok sayıdaki değişken arasında birlikte değişimin varlığını veya derecesini belirleme amacıyla korelasyon türü ilişki ile ve karşılaştırma yoluyla elde edilen ilişkisel çözümlemeler yapılabilmektedir (Karasar, 2017, s. 24).

\section{Çalışma Grubu}

Araştırma, 2016-2017 eğitim-öğretim yılında Muğla ilinde bulunan Menteşe ilçe merkezinde özel, resmi anaokulu ve ilkokullarında eğitim alan ve 2017-2018 eğitim-öğretim yılında ilkokula başlayacak olan okul öncesi çocukları ile gerçekleştirilmiştir. Örneklem, evrenden oransız kademeli örnekleme yöntemiyle random (tesadüfî) olarak belirlenmiş ve toplamda 7 okulda eğitim alan çocuklara ilgili ölçekler uygulanmıştır. Kademeli örneklem, kümeler çok sayıda alındığında örneklem aşırı ölçüde büyüyorsa, seçilen her küme içinden de küme ya da eleman örneklemesine gidilmesi olarak ifade edilebilir (Karasar, 2017, s. 25).

$\mathrm{Bu}$ anlamda, araştırma özel anaokulunda eğitim alan çocuklardan 45, resmi anaokulunda eğitim alan çocuklardan 108, ilkokulların anasınıflarına devam eden okul öncesi çocuklardan 102 olmak üzere toplam 255 çocuk ile gerçekleştirilmiştir. Örneklem grubunun 124'ü $(\% 48,6)$ kız çocuklardan oluşurken, 131'i $(\% 51,4)$ erkek çocuklardan oluşmaktadır. Bununla birlikte araştırmaya katılan çocukların ailelerinde 2 çocuğa sahip olanların sayısının diğerlerine oranla çoğunlukta olduğu görülmektedir. Yine araştırmaya katılan çocukların çoğunluğu 19-24 ay ve iki yıldan fazla süredir bir okul öncesi kuruma devam etmektedirler Bunun yanında araştırmaya katılan çocukların annelerinin ve babalarının çoğunluğu 30-39 yaş aralığındadır. Araştırmaya katılan çocukların annelerinin çoğunluğu lise mezunu iken babalarının çoğunluğu üniversite mezunudur. Araştırmaya katılan çocukların annelerinin çoğunluğu herhangi bir işte çalışmamakta, babalarının çoğunluğu ise herhangi bir işte çalışmaktadır.

\section{Veri Toplama Araçları}

\section{Genel Bilgi Formu}

Araştırmanın demografik özellikleri hakkında veri toplamak amacıyla araştırmacı tarafından geliştirilen genel bilgi formu; çocukların demografik özelliklerini belirlemeye yönelik toplam altı sorudan (cinsiyet, ailedeki çocuk sayısı, çocuğun herhangi bir okul öncesi kuruma devam etme süresi, annenin ve babanın yaşı, annenin ve babanın öğrenim durumu, annenin ve babanın çalışma durumu) oluşmaktadır.

\section{Okul Öncesi Öz Düzenleme Ölçeği}

Okul Öncesi Öz Düzenleme Ölçeği (OÖDÖ), Smith-Donald ve arkadaşları (2007) tarafından geliştirilmiştir ve performansa dayalı değerlendirme yapılmasını sağlayan bir ölçme aracıdır. Fındık Tanrıbuyurdu (2012) tarafından Türkiye'de yapılan geçerlik ve güvenirlik çalışması sonucunda ölçeğin geçerliğine ilişkin yapılan açımlayıcı faktör analizi sonuçlarında ölçeğin orijinaline uygun olarak Dikkat/Dürtü Kontrolü ve Olumlu Duygu olmak üzere iki faktörden oluştuğu belirlenmiştir. Ölçeğin güvenirliğine ilişkin hesaplanan Cronbach alfa katsayısının ( $\alpha$ ) .83 olduğu belirlenmiştir. Bu haliyle Okul Öncesi Öz Düzenleme Ölçeği'nin, Türkiye'deki çocukların öz düzenlemelerini değerlendirmek için güvenilir bir ölçme aracı olduğu söylenebilir. Ölçeğin alt boyutlarına ilişkin Cronbach alfa güvenirlik katsayıları $(\alpha)$ ise Dikkat/Dürtü Kontrolü için .88 ve Olumlu Duygu alt boyutu için .80 olarak belirlenmiştir. Ölçeğin tamamından elde edilen güvenirlik katsayısına benzer şekilde, iki faktörün de güvenirlik katsayılarının yeterli olduğu görülmektedir. Ölçeğin test-tekrar test güvenirliği için Spearman Brown korelasyon katsayısı kullanılmıştır. Analizler sonucunda anlamlı düzeyde korelasyon elde edilmiştir ve korelasyon katsayısı .86 olarak bulunmuştur. Okul Öncesi Öz Düzenleme Ölçeği, çocukların dikkat, duygu ve dürtülerini ölçmek için güvenilir bir testtir.

\section{Metropolitan Okula Hazır Bulunuşluk Testi}

Metropolitan Okul Olgunluk Testi, G.H. Hiltreth ve arkadaşları (1949) tarafından okula yeni başlayanların 1. sınıfa hazırlıklı olmalarını sağlayacak olan özellikleri ve başarılarını ölçmek için geliştirilmiştir ve Oktay tarafından 1980 yılında Türkçeye uyarlanmıştır. 6 ayrı alt boyutu olan test 16 sayfalık bir kitapçıktan oluşmaktadır. Testin 19 maddesi kelime anlama alt boyutunu oluştururken, 14 maddesi cümle anlama alt boyutunu oluşturmaktadır. Bunların yanında 14 maddesi genel bilgi, 19 maddesi eşleştirme, 24 maddesi sayılar ve 10 maddesi de kopya etme alt boyutunu oluştumaktadır. Uygulayıcı tarafından sözlü olarak verilen yönergeler doğrultusunda çocuğun işaretleyeceği ya da kopya edeceği toplam 100 maddeden meydana gelmektedir.

Birçok ülkede uygulanmakta olan Metropolitan Olgunluk Testi, standart bir test olmakla birlikte geçerlik ve güvenirlik çalışmaları bir çok kez yapılmıştır. Oktay tarafından 1980 yılında testin geçerlik ve güvenirlik çalışmaları Türkçe'ye uyarlama 
sırasında uygulanmıştır. Türkçe Formun Normları, babaları yüksek öğrenim görmüş ve İstanbul'un sosyo-ekonomik düzeyi en yüksek bölgelerindeki okullardan seçilen 35 kız ve 35 erkekten oluşan 70 çocuk ile baba-ları en fazla ilkokul öğrenimi görmüş ve şehrin sosyo-ekonomik düzeyi en düşük bölgelerindeki okullara devam eden 35 kız 35 erkekten oluşan 70 çocuk olmak üzere, toplam 140 çocuk üzerinde uygulanarak belirlenmiştir. Çocukların puan ortalamaları ve standart sapma değerleri hesaplanmıştır. Uyum geçerliliği için ise İstanbul normları ile Amerikan normları karşılaştırılmış, İstanbul'un sosyo-ekonomik düzeyi en yüksek bölgelerindeki okullardan seçilmiş olan çocukların ortalama ve standart sapmaları ile Amerikan çocuklarının ortalama ve standart sapmaları arasında benzerlikler bulunmuştur. Yapı Geçerliği için İstanbul normlarını oluşturan her iki grubun puanları t testi ile karşılaştırılmış ve her alt test için iki grup arasında 0.001 düzeyinde, avantajlı grubun lehine anlamlı farklılıklar bulunmuştur. Alt boyutların birbirleriyle ve her birinin okuma olgunluğu ve genel olgunlukla ilişkileri her iki grup için ayrı ayrı incelenmiştir. Elde edilen korelasyon katsayıları avantajı grup için 0.17 ile 0.94 arasında değişmiştir (Öner, 2008; 53).

Sonuç olarak, Metropolitan Olgunluk Testi çocuğun yönergeyi anlama ve uygulama becerisini ölçmektedir. 6 alt test, 100 madde ve 16 sayfalık bir kitapçıktan oluşmaktadır. Araştırmacı tarafından sözlü olarak verilen yönergeye göre öğrencinin işaretlediği veya kopya ettiği resimlerin her doğru cevabına 1 puan verilmekte, yanlış yaptıklarına ise puan verilmemektedir. Bu durum alt boyutların puanlanmasında da aynıdır. Örneğin genel bilgi alt testinde madde sayısı 14'tür ve bu alt testten alınabilecek en yüksek puan 14 , en düşük puan ise 0 'dır.

\section{Verilerin Toplanması}

Veri toplama araçlarının araştırmada kullanılabilmesi için “Okul Öncesi Öz Düzenleme Ölçeği”nin Türkçe’ye uyarlama çalışmalarını yapan Fındık Tanrıbuyurdu (2012)' dan gerekli izinler alınmıştır. Aynı zamanda veri toplama araçlarının özel - resmi anaokulları ve ilkokul anasınıflarında uygulanabilmesi için Muğla il Milli Eğitim Müdürlüğü’nden izin alındıktan sonra araştırmacı tarafından ilgili okullara gidilerek, uygulamanın amacıyla ilgili gerekli açıklamalar yapılmış, ardından belirlenen her çocuk sırayla alınarak sessiz ve sakin bir odada ölçekler uygulanmıştır.

Örnekleme alınan çocuklara öncelikle okul öncesi öz düzenleme ölçeği ardından metropolitan okula hazırbulunuşluk testi uygulanmıştır. Ölçekler 1 Mart - 2 Haziran 2017 tarihleri arasındaki 13 haftalık süreç içerisinde, haftanın dört günü, günde 5 çocuğa uygulama yapılabilecek şekilde uygulanmıştır.

\section{Verilerin Analizi}

Araştırma sürecinde elde edilen veriler, SPSS 22.0 istatistik paket programı aracılığıyla çözümlenmiştir. Verilerin analizinde, öncelikle elde edilen verilerin normal dağılım gösterip göstermediği Kolmogorov-Smirnov testi ile incelenmiştir. Buna göre, elde edilen verilerle her iki ölçeğinde normal dağılım göstermediği görülmüştür. Bunun üzerine ölçeklerin çarpıklık ve basıklık katsayıları incelenerek normallik testi yapılmıştır. Test sonucunda elde edilen değerlere göre dağılımın normalliğinin kabul edilebilir olduğu görülmüştür. Büyük gruplar üzerinden toplanan verilerin, normal dağılıma yakın dağılım gösterdikleri kabul edilebilir ve buna göre parametrik istatistikler seçilebilir. Dağılımın normal dağılımdan aşırı sapma göstermediği şeklinde bir varsayımı ileri sürmek için öngörülen örneklem büyüklüğü genellikle 30 ve daha büyük olarak gösterilmektedir (Büyüköztürk, 2013, s. 23).

Ardından genel bilgi formlarına bağlı olarak demografik özelliklerin frekans ve yüzde dağılımları bulunduktan sonra çocukların öz düzenleme becerileri ve ilkokula hazırbulunuşluk düzeylerinin aritmetik ortalamaları ve standart sapmaları belirlenmiş, öz düzenleme beceri düzeylerinin ilkokula hazırbulunuşluk düzeyleri üzerindeki etkisi belirlemek üzere 'Basit Doğrusal Regresyon Analizi' kullanılmıştır. Öz düzenleme becerileri bağımsız değişken, ilkokula hazırbulunuşluk düzeyleri ise bağımlı değişken olarak alınmıştır. Daha sonra örneklem grubu için öz düzenleme ölçeğinden ve hazırbulunuşluk testinden alınan puanların; cinsiyete ve annenin-babanın çalışma durumuna göre farklılaşıp farklılaşmadığını belirlemek üzere "Bağımsız grup t-testi”; ailedeki çocuk sayısı, çocuğun herhangi bir okul öncesi kuruma devam etme süresi, annenin ve babanın yaşı, annenin ve babanın öğrenim durumuna göre farklılaşıp farklılaşmadığını belirlemek üzere "Anova testi" kullanılmıştır. Hazırbulunuşluk testi toplam puanı, öz düzenleme dikkat/dürtü kontrolü alt boyutu, olumlu duygu alt boyutlarından alınan puanlar ile öz düzenleme toplam puanı, hazırbulunuşluk testi okuma hazırlığı, sayı hazırlığı ve kopya etme beceri puanından alınan puanların arasındaki ilişkiyi incelemek amacıyla da pearson momentler çarpımı korelasyonu kullanılmıştır.

\section{BULGULAR}

Araştırma değişkenlerinin demografik özelliklere göre farklılaşma durumuna ilişkin bulgular ve bunlara yönelik yorumlar aşağıda yer alan tablolarda verilmiştir. 
Tablo 1. Çocukların Öz Düzenleme Genel Beceri Puanlarının Cinsiyet, Annenin ve Babanın Çalışma Durumu Değişkenlerine Göre Bağımsız Grup T-testi Sonuçları

\begin{tabular}{|c|c|c|c|c|c|c|}
\hline Değişken & & $\mathrm{N}$ & $\mathrm{S}$ & $\mathrm{sd}$ & $\mathrm{t}$ & $p$ \\
\hline \multirow{2}{*}{ Cinsiyet } & $\mathrm{K} ı \mathrm{Z}$ & 124 & 8,008 & 253 & $-0,722$ & 0,471 \\
\hline & Erkek & 131 & 8,411 & & & \\
\hline Annenin Çalışma & Çalışmıyor & 113 & 7,732 & 253 & $-0,321$ & 0,748 \\
\hline Durumu & Çalışıyor & 142 & 8,595 & & & \\
\hline Babanın Çalışma & Çalışmıyor & 15 & 7,493 & 253 & $-0,369$ & 0,712 \\
\hline Durumu & Calısııyor & 240 & 8,264 & & & \\
\hline
\end{tabular}

Tablo 1'de görüldüğü gibi cinsiyet değişkenine göre çocukların öz düzenleme genel beceri puanları $(p=, 471)$ arasında da istatistiksel olarak anlamlı bir farklılık bulunmamıştır ( $p>.05)$. Buna göre erken çocukluk dönemi çocuklarının öz düzenleme beceri düzeylerinin cinsiyet değişkenine göre istatistiksel olarak farklılaşmadığı söylenebilir. Ayrıca annenin çalışma durumu değişkenine göre çocukların öz düzenleme toplam puanları $(p=, 748)$ arasında da istatistiksel olarak anlamlı bir farklılık bulunmamıştır ( $p>.05)$. Buna göre erken çocukluk dönemi çocuklarının öz düzenleme becerisi düzeylerinin annenin çalışma durumu değişkenine göre istatistiksel olarak farklılaşmadığı söylenebilir. Bunun yanında babanın çalışma durumu değişkenine göre çocukların öz düzenleme toplam puanları $(p=, 712)$ arasında istatistiksel olarak anlamlı bir farklılık bulunmamıştır ( $p>.05)$. Buna göre erken çocukluk dönemi çocuklarının öz düzenleme beceri düzeylerinin babanın çalışma durumu değişkenine göre istatistiksel olarak farklılaşmadığı söylenebilir.

Tablo 2. Çocukların Öz Düzenleme Puanlarının Ailedeki Çocuk Sayısı, Çocuğun Herhangi Bir Okul Öncesi Kuruma Devam Etme Süresi, Annenin Yaşı, Babanın Yaşı, Annenin Öğrenim Durumu ve Babanın Öğrenim Durumu Değişkenlerine Göre Anova Testi Sonuçları

\begin{tabular}{|c|c|c|c|c|c|c|}
\hline Değişken & Varyansın Kaynağı & Kareler Toplamı & sd & $\begin{array}{c}\text { Kareler } \\
\text { Ortalaması }\end{array}$ & $\mathrm{F}$ & $\mathrm{p}$ \\
\hline \multirow{3}{*}{ Ailedeki Çocuk Sayısı } & Gruplar arası & 34,266 & 3 & 11,422 & 168 & 0,918 \\
\hline & Grup İçi & 17084,142 & 251 & 68,064 & & \\
\hline & Toplam & 17118,408 & 254 & & & \\
\hline \multirow{3}{*}{$\begin{array}{l}\text { Çocuğun Herhangi Bir Okul } \\
\text { Öncesi Kuruma Devam Etme } \\
\text { Süresi }\end{array}$} & Gruplar arası & 6633,572 & 4 & 1658,393 & 39,543 & 0,000 \\
\hline & Grup İçi & 10484,836 & 250 & 41,939 & & \\
\hline & Toplam & 17118,408 & 254 & & & \\
\hline \multirow{3}{*}{ Annenin Yaşı } & Gruplar arası & 41,44 & 2 & 20,72 & 0,306 & 0,737 \\
\hline & Grup İçi & 17076,967 & 252 & 67,766 & & \\
\hline & Toplam & 17118,408 & 254 & & & \\
\hline \multirow{3}{*}{ Babanın Yaşı } & Gruplar arası & & 2 & 27,104 & 1,797 & 0,168 \\
\hline & Grup İçi & & 252 & 15,08 & & \\
\hline & Toplam & & 254 & & & \\
\hline \multirow{3}{*}{ Annenin Öğrenim Durumu } & Gruplar arası & 865,506 & 2 & 432,753 & 6,71 & 0,001 \\
\hline & Grup İçi & 16252,902 & 252 & 64,496 & & \\
\hline & Toplam & 17118,408 & 254 & & & \\
\hline \multirow{3}{*}{ Babanın Öğrenim Durumu } & Gruplar arası & 884,381 & 2 & 442,19 & 6,864 & 0,001 \\
\hline & Grup İçi & 16234,027 & 252 & 64,421 & & \\
\hline & Toplam & 17118,408 & 254 & & & \\
\hline
\end{tabular}

Tablo 2 incelendiğinde ailedeki çocuk sayısı değişkenine göre çocukların öz düzenleme toplam puanları $(p=, 918)$ arasında da istatistiksel olarak anlamlı bir farklılık bulunmamıştır ( $p>.05)$. Buna göre erken çocukluk dönemi çocuklarının öz düzenleme beceri düzeylerinin ailedeki çocuk sayısı değişkenine göre istatistiksel olarak farklılaşmadığı söylenebilir. Bununla birlikte çocuğun herhangi bir okul öncesi kuruma devam etme süresi değişkenine göre çocukların öz düzenleme toplam puanları $(p=, 000)$ arasında istatistiksel olarak anlamlı bir farklılık bulunmuştur ( $p<.05)$. Yapılan Tukey çoklu karşılaştırma testi sonucunda, 0-6 ay ve 7-12 ay; 0-6 ay ve 13-18 ay; 0-6 ay ve 19-24 ay; 0-6 ay ve iki yıldan fazla; 7-12 ay ve 0-6 ay; 7-12 ay ve $13-18$ ay; 7-12 ay ve $19-24$ ay; 7-12 ay ve iki yıldan fazla; $13-18$ ay ve 0-6 ay; $13-18$ ay ve 7-12 ay; $13-18$ ay ve iki yıldan fazla; $19-24$ ay ve 0-6 ay; $19-24$ ay ve 7-12 ay; iki yıldan fazla ve 0-6 ay; iki yıldan fazla ve 7-12 ay; iki yıldan fazla ve 13-18 ay; iki yıldan fazla ve 19-24 ay grupları ortalamaları arasında anlamlı farklılık olduğu bunların dışında yer alan grupların ortalamaları arasında anlamlı farklılık olmadığı sonucuna ulaşılmıştır. Buna göre erken çocukluk dönemi çocuklarının öz düzenleme becerisi düzeylerinin çocuğun herhangi bir okul öncesi kuruma devam etme süresi değişkenine göre istatistiksel olarak farklılaştığı söylenebilir. Bunun yanında annenin yaşı değişkenine göre çocukların öz düzenleme toplam puanları $(p=, 737)$ arasında istatistiksel olarak anlamlı bir farklılık bulunmamıştır ( $p>.05)$. Buna göre erken çocukluk dönemi çocuklarının öz düzenleme düzeylerinin annenin yaşı değişkenine göre istatistiksel olarak farklılaşmadığı söylenebilir. Babanın yaşı değişkenine göre çocukların öz düzenleme toplam puanları $(p=, 168)$ arasında da istatistiksel olarak anlamlı bir farklılık bulunmamıştır ( $p>.05)$. Buna göre erken çocukluk dönemi çocuklarının öz düzenleme becerisi düzeylerinin babanın yaşı değişkenine göre istatistiksel olarak farklılaşmadığı söylenebilir. Bunların yanında annenin öğrenim durumu değişkenine göre çocukların öz düzenleme toplam puanları $(p=, 001)$ arasında istatistiksel olarak anlamlı bir farklılık bulunmuştur ( $p<.05)$. Yapılan Tukey çoklu karşılaştırma testi sonucunda, ilkokul/ortaokul ve lise; ilkokul/ortaokul ve üniversite; lise

|Kastamonu Eğitim Dergisi, 2020, Vol. 28, No. 5 | 
ve ilkokul/ortaokul; üniversite ve ilkokul/ortaokul gruplarının ortalamaları arasın-da anlamlı farklılık olduğu, bu grubun dışında kalan grup ortalamaları arasında anlamlı farklıık olmadığı sonucuna ulaşılmıştır. Buna göre erken çocukluk dönemi çocuklarının öz düzenleme becerisi düzeylerinin annenin öğrenim durumu değişkenine göre istatistiksel olarak farklılaştığı söylenebilir. Ayrıca babanın öğrenim durumu değişkenine göre çocukların öz düzenleme toplam puanları $(p=, 001)$ arasında da istatistiksel olarak anlamlı bir farklılık bulunmuştur $(p<.05)$. Yapılan Tukey çoklu karşılaştırma testi sonucunda, lise-üniversite ve üniversite-lise gruplarının ortalamaları arasında anlamlı farklılık olduğu, bu grubun dışında kalan grup ortalamaları arasında anlamlı farklılık olmadığı sonucuna ulaşılmıştır. Buna göre erken çocukluk dönemi çocuklarının öz düzenleme becerisi düzeylerinin babanın öğrenim durumu değişkenine göre istatistiksel olarak farklılaştığı söylenebilir.

Tablo 3. Çocukların illkokula Hazırbulunuşluk Puanlarının Cinsiyet, Annenin ve Babanın Çalışma Durumu Değişkenlerine Göre Bağımsız Grup T-testi Sonuçları

\begin{tabular}{|c|c|c|c|c|c|c|}
\hline Değişken & & $\mathrm{N}$ & $S$ & sd & $\mathrm{t}$ & $p$ \\
\hline \multirow{2}{*}{ Cinsiyet } & $K_{12}$ & 124 & 18,428 & 253 & $-0,234$ & ,815 \\
\hline & Erkek & 131 & 18,406 & & & \\
\hline Annenin Çalışma & Çalışmıyor & 113 & 16,982 & 253 & $-0,155$ & 877 \\
\hline Durumu & Çalışıyor & 142 & 19,483 & & & \\
\hline Babanın Çalışma & Çalışmıyor & 15 & 21,914 & 253 & $-0,819$ & ,414 \\
\hline Durumu & Çalışıyor & 240 & 18,167 & & & \\
\hline
\end{tabular}

Tablo 3'te görüldüğü gibi, cinsiyet değişkenine göre çocukların ilkokula hazırbulunuşluk toplam puanları $(p=, 815)$ arasında istatistiksel olarak anlamlı bir farklılık bulunmamıştır ( $p>.05$ ). Buna göre erken çocukluk dönemi çocuklarının ilkokula hazırbulunuşluk düzeylerinin cinsiyet değişkenine göre istatistiksel olarak farklılaşmadığı söylenebilir. Bunun yanında annenin çalışma durumu değişkenine göre çocukların ilkokula hazırbulunuşluk toplam puanları $(p=, 877)$ arasında da istatistiksel olarak anlamlı bir farklılık bulunmamıştır ( $p>$.05). Buna göre erken çocukluk dönemi çocuklarının ilkokula hazırbulunuşluk düzeylerinin annenin çalışma durumu değişkenine göre istatistiksel olarak farklılaşmadığı söylenebilir. Ayrıca babanın çalışma durumu değişkenine göre çocukların ilkokula hazırbulunuşluk toplam puanları $(p=, 414)$ arasında da istatistiksel olarak anlamlı bir farklılık bulunmamıştır ( $p>$.05). Buna göre erken çocukluk dönemi çocuklarının ilkokula hazırbulunuşluk düzeylerinin babanın çalışma durumu değişkenine göre istatistiksel olarak farklılaşmadığı söylenebilir.

Tablo 4. Çocukların ilkkokula Hazırbulunuşluk Puanlarının Ailedeki Çocuk Sayısı, Çocuğun Herhangi Bir Okul Öncesi Kuruma Devam Etme Süresi, Annenin Yaşı, Babanın Yaşı, Annenin Öğrenim Durumu ve Babanın Öğrenim Durumu Değişkenlerine Göre Anova Testi Sonuçları

\begin{tabular}{|c|c|c|c|c|c|c|}
\hline Değişken & Varyansın Kaynağı & Kareler Toplamı & sd & $\begin{array}{c}\text { Kareler } \\
\text { Ortalaması }\end{array}$ & $\mathrm{F}$ & $p$ \\
\hline & Gruplar arası & 342,59 & 3 & 114,197 & 335 & 800 \\
\hline \multirow[t]{2}{*}{ Ailedeki Çocuk Sayısı } & Grup İçi & 85486,217 & 251 & 340,583 & & \\
\hline & Toplam & 85828,808 & 254 & & & \\
\hline Çocuğun Herhangi Bir Okul & Gruplar arası & 48952,428 & 4 & 12238,107 & 967 & 000 \\
\hline Öncesi Kuruma Devam Etme & Grup İçi & 36876,38 & 250 & 147,506 & & \\
\hline \multirow[t]{2}{*}{ Süresi } & Toplam & 85828,808 & 254 & & & \\
\hline & Gruplar arası & 388,486 & 2 & 194,243 &, 573 &, 565 \\
\hline \multirow[t]{3}{*}{ Annenin Yaşı } & Grup İçi & 85440,322 & 252 & 339,049 & & \\
\hline & Toplam & 85828,808 & 254 & & & \\
\hline & Gruplar arası & 158,177 & 2 & 79,088 & ,233 & ,793 \\
\hline \multirow[t]{3}{*}{ Babanın Yaşı } & Grup İçi & 85670,631 & 252 & 339,963 & & \\
\hline & Toplam & 85828,808 & 254 & & & \\
\hline & Gruplar arası & 5057,807 & 2 & 2528,903 & 7,89 & ,000 \\
\hline \multirow[t]{3}{*}{ Annenin Öğrenim Durumu } & Grup İçi & 80771,001 & 252 & 320,52 & & \\
\hline & Toplam & 85828,808 & 254 & & & \\
\hline & Gruplar arası & 6108,826 & 2 & 3054,413 & 9,655 & ,000 \\
\hline \multirow[t]{2}{*}{ Babanın Öğrenim Durumu } & Grup İçi & 79719,982 & 252 & 316,349 & & \\
\hline & Toplam & 85828,808 & 254 & & & \\
\hline
\end{tabular}

Tablo 4. incelendiğinde ailedeki çocuk sayısı değişkenine göre çocukların ilkokula hazırbulunuşluk toplam puanları ( $p=, 800$ ) arasında istatistiksel olarak anlamlı bir farklılık bulunmamıştır ( $p>$.05). Buna göre erken çocukluk dönemi çocuklarının ilkokula hazırbulunuşluk düzeylerinin ailedeki çocuk sayısı değişkenine göre istatistiksel olarak farklılaşmadığı söylenebilir. Bununla birlikte çocuğun herhangi bir okul öncesi kuruma devam etme süresi değişkenine göre çocukların ilkokula hazırbulunuşluk toplam puanları $(p=, 000)$ arasında istatistiksel olarak anlamlı bir farklılık bulunmuştur $(p<.05)$. Yapılan Tukey çoklu karşılaştırma testi sonucunda, tüm grupların ortalamaları arasında anlamlı farklılık olduğu sonucuna ulaşılmıştır. Buna göre erken çocukluk dönemi çocuklarının ilkokula hazırbulunuşluk düzeylerinin çocuğun herhangi bir okul öncesi kuruma devam etme süresi değişkenine göre istatistiksel olarak farklılaştığı söylenebilir. Bununla birlikte annenin yaşı değişkenine göre çocukların ilkokula hazırbulunuşluk toplam puanları 
$(p=, 565)$ arasında istatistiksel olarak anlamlı bir farklılık bulunmamıştır ( $p>$.05). Buna göre erken çocukluk dönemi çocuklarının ilkokula hazırbulunuşluk düzeylerinin annenin yaşı değişkenine göre istatistiksel olarak farklılaşmadığı söylenebilir. Ayrıca babanın yaşı değişkenine göre çocukların ilkokula hazırbulunuşluk puanları $(p=, 793)$ arasında da istatistiksel olarak anlamlı bir farklılık bulunmamıştır ( $p>$.05). Buna göre erken çocukluk dönemi çocuklarının ilkokula hazırbulunuşluk düzeylerinin babanın yaşı değişkenine göre istatistiksel olarak farklılaşmadığı söylenebilir. Bunlarla birlikte annenin öğrenim durumu değişkenine göre çocukların ilkokula hazırbulunuşluk toplam puanları $(p=, 000)$ arasında ise istatistiksel olarak anlamlı bir farklılık bulunmuştur ( $\mathrm{p}$ <.05). Yapılan Tukey çoklu karşılaştırma testi sonucunda, ilkokul/ortaokul-lise ve ilkokul/ortaokul-üniversite grupları ortalamaları arasında anlamlı farklılık olduğu sonucuna ulaşılmıştır. Buna göre erken çocukluk dönemi çocuklarının ilkokula hazırbulunuşluk düzeylerinin annenin öğrenim durumu değişkenine göre istatistiksel olarak farklılaştığı söylenebilir. Bunların yanında babanın öğrenim durumu değişkenine göre çocukların ilkokula hazırbulunuşluk toplam puanları $(p=, 000)$ arasında istatistiksel olarak anlamlı bir farklılık bulunmuştur ( $p<.05)$. Yapılan Tukey çoklu karşılaştırma testi sonucunda, ilkokul/ortaokul ve üniversite; lise ve üniversite; üniversite ve ilkokul/ortaokul; üniversite ve lise grupları ortalamaları arasında anlamlı farklılık olduğu bunların dışında yer alan grupların ortalamaları arasında anlamlı farklılık olmadığı sonucuna ulaşımıştır. Buna göre erken çocukluk dönemi çocuklarının ilkokula hazırbulunuşluk düzeylerinin babanın öğrenim durumu değişkenine göre istatistiksel olarak farklılaştığı söylenebilir

Tablo 5. Öz Düzenleme Becerileri İle İlkokula Hazırbulunuşluk Arasındaki ilişskiye Yönelik Regresyon Analizi Sonuçları

\begin{tabular}{lccccc}
\hline Değişkenler & B & Standart Hata B & B & t & p \\
\hline İlkokula Hazırbulunuşluk Düzeyi (sabit) & 8,211 & 2,714 & & 3,026 & 0,003 \\
Öz Düzenleme Becerisi & 1,838 & 0,80 & 821 & 22,876 & 0,000 \\
\hline
\end{tabular}

$R=.821 R^{2}=.674 p=.000 F=523,292$

Tablo 5'te yer alan istatistiksel veriler incelendiğinde öz düzenleme becerileri ile ilkokula hazırbulunuşluk arasında pozitif yönde, yüksek düzeyde ve anlamlı bir ilişkinin olduğu $(r=.821, p<.05)$ görülmektedir. İlişki katsayısının 1.00 olması mükemmel bir pozitif ilişkiyi ifade ederken, -1.00 olması mükemmel negatif bir ilişkiyi ve 0.00 olması ise ilişkinin olmadığını ifade etmektedir. iliş̧ki katsayısının mutlak değer olarak $0.70-1.00$ arasında olması yüksek, $0.70-0.30$ arasında olması orta ve $0.30-0.00$ arasında olması ise düşük bir ilişkiyi ifade etmektedir (Büyüköztürk, 2013, s. 43). Bu sonuca göre erken çocukluk döneminde yer alan çocukların öz düzenleme beceri düzeyleri arttıkça ilkokula hazırbulunuşluk düzeylerinin de arttığı, öz düzenleme beceri düzeyleri düştükçe ilkokula hazırbulunuşluk düzeylerinin de düştüğü söylenebilir.

Tablo 5'te görüldüğü gibi öz düzenleme beceri düzeyinin bağımsız değişken, ilkokula hazırbulunuşluk düzeyinin bağımlı değişken olarak kullanıldığı regresyon analizi sonuçlarına göre bağımlı değişkenin açıklanma düzeyi istatistiksel olarak anlamlıdır (R=.821, $\left.\mathrm{R}^{2}=.674, \mathrm{p}<.05\right)$. Elde edilen bulgulara göre, öz düzenleme becerilerinin ilkokula hazırbulunuşluk düzeylerini yordama gücü \% 67 'dir. Analiz sonuçlarına göre öz düzenleme becerilerinin ilkokula hazırbulunuşluk üzerinde anlamlı bir yordayıcısı olduğu ifade edilebilir.

\begin{tabular}{llllll}
\hline Değişkenler & \multicolumn{2}{c}{ Standart Hata } & B & t & p \\
\hline Ilkokula Hazır Bulunuşluk Düzeyi (sabit) & 8,211 & 2,714 & 3,026 & 0,003 \\
Öz Düzenleme Becerisi & 1,838 & 0,8 & 821 & 22,876 & 0
\end{tabular}

Tablo 6. Okul Öncesi Öz Düzenleme Ölçeği ve Alt Boyutları ile Metropolitan ilkokula Hazırbulunuşluk Ölçeği ve Alt Boyutları Arasındaki iliş̧kiye Yönelik Pearson Momentler Çarpımı Korelasyonu Katsayısı Sonuçları

\begin{tabular}{|c|c|c|c|c|c|}
\hline \multirow[b]{2}{*}{$\begin{array}{l}\text { Okul Öncesi Öz } \\
\text { Düzenleme Ölçeği }\end{array}$} & & \multicolumn{4}{|c|}{ Metropolitan İlkokula Hazırbulunuşluk Ölçeği } \\
\hline & & Okuma Hazırlığı & Sayı Hazırlığı & Kopya Etme Becerisi & $\begin{array}{c}\text { İlkokula Hazırbulunuşluk Genel } \\
\text { Becerisi }\end{array}$ \\
\hline \multirow{3}{*}{ Dikkat-Dürtü Kontrolü } & $r$ & 0,766 & 0,362 & 0,145 & 0,778 \\
\hline & $\mathrm{p}$ & 0,000 & 0,000 & 0,02 & 0,000 \\
\hline & $\mathrm{N}$ & 255 & 255 & 255 & 255 \\
\hline \multirow{3}{*}{ Olumlu Duygu } & $r$ & 0,684 & 0,238 & 0,089 & 0,681 \\
\hline & $\mathrm{p}$ & 0,000 & 0,000 & 0,158 & 0,000 \\
\hline & $\mathrm{N}$ & 255 & 255 & 255 & 255 \\
\hline \multirow{3}{*}{$\begin{array}{l}\text { Öz Düzenleme } \\
\text { Genel Becerisi }\end{array}$} & $r$ & 0,815 & 0,346 & 0,136 & \\
\hline & $p$ & 0,000 & 0,000 & 0,03 & \\
\hline & $\mathrm{N}$ & 255 & 255 & 255 & \\
\hline
\end{tabular}

Tablo 6'da görüldüğü gibi, çocukların ilkokula hazırbulunuşluk puanları ile dikkat-dürtü kontrolü puanları arasında pozitif yönde anlamlı bir ilişki olduğu görülmektedir, ( $N=255$ r=-.778, p<.01). Bu sonuçlara göre çocukların dikkat-dürtü kontrolü düzeyleri arttıkça ilkokula hazırbulunuşluk düzeylerinin de arttığı anlaşılmaktadır. Aynı zamanda çocukların ilkokula hazırbulunuşluk puanları 
ile olumlu duygu puanları arasında da pozitif yönde anlamlı bir ilişki olduğu görülmektedir ( $\mathrm{N}=255 \mathrm{r}=-.681, \mathrm{p}<.01)$. Bu sonuçlara göre çocukların olumlu duygu düzeyleri arttıkça ilkokula hazırbulunuşluk düzeylerinin de arttığı anlaşılmaktadır. Ayrıca çocukların öz düzenleme puanları ile okuma hazırlığı puanları arasında da pozitif yönde anlamlı bir ilişki olduğu görülmektedir, (N=255 r=$.815, p<.01)$. Bu sonuçlara göre çocukların öz düzenleme beceri düzeyleri arttıkça okuma hazırlığı düzeylerinin de arttığı anlaşılmaktadır. Bununla birlikte çocukların öz düzenleme puanları ile sayı hazırlığı puanları arasında pozitif yönde anlamlı bir ilişki olduğu görülmektedir, ( $N=255$ r=-.346, p<.01). Bu sonuçlara göre çocukların öz düzenleme beceri düzeyleri arttıkça sayı hazırlığı düzeylerinin de arttığı anlaşılmaktadır. Tablo incelendiğinde çocukların öz düzenleme puanları ile kopya etme puanları arasında da pozitif yönde anlamlı bir ilişki olduğu görülmektedir, ( $N=255 r=-.136, p<.01)$. Bu sonuçlara göre çocukların öz düzenleme beceri düzeyleri arttıkça kopya etme beceri düzeylerinin de arttığı anlaşılmaktadır.

Tablo incelendiğinde çocukların dikkat-dürtü kontrolü puanları ile okuma hazırlığı puanları arasında pozitif yönde anlamlı bir ilişki olduğu görülmektedir. ( $N=255$ r=.766 p<.01). Bu sonuçlara göre çocukların dikkat-dürtü kontrolü düzeyleri arttıkça okuma hazırlığı düzeylerinin de aynı doğrultuda arttığı anlaşımaktadır. Bununla birlikte çocukların dikkat-dürtü kontrolü puanları ile sayı hazırlığı puanları arasında da pozitif yönde anlamlı bir ilişki olduğu görülmektedir ( $\mathrm{N}=255 \mathrm{r}=.362 \mathrm{p}<.01$ ). Bu sonuçlara göre çocukların dikkat-dürtü kontrolü düzeyleri arttıkça sayı hazırlığı düzeylerinin de aynı doğrultuda arttığı anlaşılmaktadır. Ayrıca çocukların dikkat-dürtü kontrolü puanları ile kopya etme beceri puanları arasında da pozitif yönde anlamlı bir ilişki olduğu görülmektedir ( $\mathrm{N}=255 \mathrm{r=}=145 \mathrm{p}<.05$ ). Bu sonuçlara göre çocukların dikkat-dürtü kontrolü düzeyleri arttıkça kopya etme beceri düzeylerinin de aynı doğrultuda arttığı anlaşılmaktadır.

Tabloda çocukların olumlu duygu puanları ile okuma hazırlığı puanları arasında pozitif yönde anlamlı bir ilişki olduğu görülmektedir $(\mathrm{N}=255 \mathrm{r=}=684 \mathrm{p}<.01)$. Buna göre çocukların olumlu duygu düzeyleri arttıkça okuma hazırlığı düzeylerinin de arttığı anlaşılmaktadır. Bununla birlikte tabloda çocukların olumlu duygu puanları ile sayı hazırlığı puanları arasında da pozitif yönde anlamlı bir ilişki olduğu görülmektedir ( $\mathrm{N}=255 \quad \mathrm{r}=.238 \quad \mathrm{p}<.05)$. Bu sonuçlara göre çocukların olumlu duygu düzeyleri arttıkça sayı hazırlığı düzeylerinin de aynı doğrultuda arttığı söylenebilir. Buna karşın çocukların olumlu duygu puanları ile kopya etme beceri puanları arasında anlamlı bir ilişki görülmemektedir ( $\mathrm{N}=255 \mathrm{r}=.089$ p>.05). Bu sonuçlara göre çocukların kopya etme becerilerinin olumlu duygu düzeylerinden etkilenmediği söylenebilir.

\section{TARTIŞMA}

Araştırma sonucunda öz düzenleme becerileri ile ilkokula hazırbulunuşluk arasında pozitif yönde anlamlı bir ilişki olduğu bulunmuştur. Bu ilişkiye göre öz düzenleme becerisi düzeyinin yüksek olması ilkokula hazırbulunuşluk düzeyinin de yüksek olduğu anlamına gelmektedir. Aynı zamanda erken çocukluk dönemi çocuklarının öz düzenleme beceri düzeylerinin, ilkokula hazırbulunuşluk düzeylerini yordadığı sonucu da elde edilmiştir. Öz düzenleme becerileri ile ilkokula hazırbulunuşluk arasındaki ilişkinin pozitif yönde ve anlamlı olması öz düzenleme becerileri yüksek çocukların okula sosyal, duygusal ve bilişsel yönden daha hazır olabilecekleri şeklinde yorumlanabilir. Çocukların yaşamlarının ileri dönemlerinde karşısına çıkabilecek akademik ve sosyal sorunlarla baş etmede zorluk yaşamaması için ilkokula hazırbulunuşluğunu tamamlaması, dolayısıyla da özdüzenleme becerilerinin geliştirilmesinin gerekli olduğu düşünülmektedir. Araştırma sonucundan hareketle çocukların erken çocukluk döneminde öz düzenleme becer-ilerini geliştirerek, ilkokula hazırbulunuşluklarını tamamlamalarına yardımcı olunabileceği, böylece çocukların okula daha kolay uyum sağlayarak, yaşamın getirdiği akademik ve sosyal sorunlarla daha kolay başedebileceği düşünülmektedir. Akawi'nin (2011) Head Start programında yer alan okul öncesi çocukları ile yapmış olduğu araştırmasında da çocukların öz düzenleme becerileri ile okula hazır oluş düzeyleri arasında pozitif yönde anlamlı bir ilişki olduğunu bulması bu bulguyu destekler niteliktedir. Bununla birlikte Riva ve Ryan (2015) öz düzenleme davranışının, genç çocukların akademik başarılarına etkisini inceledikleri araştırmalarında, okul öncesi çevreden resmi okula geçiş yapan çocuklarda öz düzenlemenin çocukların akademik sonuçlarını etkilediği sonucuna varmışlardır. Ayrıca iyi bir öz düzenleyici olan çocukların, daha sonraki ilkokul notlarında öz düzenleme yapamayanlardan daha yüksek bir akademik başarı gösterecekleri sonucuna da ulaşmışlardır. Bu sonuç ta araştırma bulgusunu destekler niteliktedir. Yine Eisenberg, Valiente ve Eggum, (2010) okula hazırbulunuşluk ve öz düzenleme becerileri arasındaki ilişkiyi inceledikleri araştırmalarında da öz düzenleme becerilerinin, okula hazır bulunuşluğu yordayan üst düzey becerilerden biri olduğu sonucuna ulaşmışlardır. Blair ve Razza da (2007) beş yaş grubu çocuklarla yaptıkları boylamsal bir araştırmada, öz düzenleme becerilerinin altı yaşta ölçülen okuma-yazma ve matematik becerilerini yordadığı sonucuna ulaşmışlardır.

Erken çocukluk dönemi çocuklarının öz düzenleme beceri düzeyleri ile ilkokula hazırbulunuşluk düzeylerinin demografik özelliklere göre anlamlı farklılık gösterip göstermediği incelendiğinde, çocukların öz düzenleme beceri düzeyleri ile ilkokula hazırbulunuşluk düzeylerinin cinsiyet değişkenine bağlı olmadığı sonucuna ulaşılmıştır. Bu durumun bir nedeninin çocukların kız veya erkek olmasının öz düzenleme beceri gelişim sürecinde ve ilkokula hazırbulunuşluk üzerinde bir etkisinin olmaması olarak gösterilebilir. Konuyla ilgili yapılan araştırmalar da benzer sonuçlar göstermektedir. Nitekim Smith-Donald ve arkadaşları (2007), yaptıkları geçerlik ve güvenirlik çalışmasında benzer şekilde cinsiyetlere göre anlamlı bir farklılık olmadığını belirlemişlerdir.

Araştırma sonuçlarından birisi ailedeki çocuk sayısının, çocukların öz düzenleme beceri düzeyleri ve ilkokula hazırbulunuşluk düzeyleri üzerinde anlamlı bir etkisinin olmadığı sonucudur. Artan ya da azalan kardeş sayısının çocukların öz düzenleme becerileri üzerinde etkisinin olmamasının çocukların bireysel farklılıklarından kaynaklana-bileceği düşünülmektedir. Her ne kadar sosyal beceriler öz düzenleme becerileri üzerinde etkili olsa da çocuklar arasındaki bireysel farklılıklar onların öz düzenleme gelişimleri üzerinde en az sosyal beceriler kadar belirleyici bir etkiye sahiptir. Ayrıca kardeş sayısının fazla olması bir yandan yaşantı zenginliği 
sağlayarak çocuğun akademik ve sosyal becerilerini destekleyebilir. Ancak diğer yandan çok çocuklu ailelerin de çocuklarına yeterli zaman ayırama-ması artan ya da azalan kardeş sayısının, çocuğun okula hazırbulunuşluğuna etki etmemesinin bir nedeni olarak gösterilebilir. Ayrıca yine araştırma sonucunda çocukların herhangi bir okul öncesi kuruma devam etme süreleri arttıkça öz düzenleme beceri düzeyleri ile ilkokula hazırbulunuşluk düzeylerinin de arttığı sonucu elde edilmiştir. Okul öncesi eğitim kurumları çocukların sosyal, duygusal ve bilişsel gelişimlerini desteklemektedir. Sosyal, duygusal ve bilişsel becerilerin öz düzenleme becerileri ile akademik gelişimine katkı sağlayan becerilerden biri olduğu düşünüldüğünde, çocukların bir okul öncesi kuruma devam etme süreleri arttıkça, öz düzenleme becerilerinin ve ilkokula hazırbulunuşluklarının aynı doğrultuda artacağı düşünülmektedir. Erken çocukluk dönemi çocuklarının öz düzenleme beceri düzeyleri ile ilkokula hazırbulunuşluk düzeylerinin annenin ve babanın yaşı değişkenlerine göre farklılaşıp farklılaşmadığı incelendiğinde, erken çocukluk dönemi çocuklarının annelerinin ve babalarının yaşının çocukların öz düzenleme beceri düzeylerine ve ilkokula hazırbulunuşluk düzeylerine etki etmediği sonucuna ulaşımıştır. Genç anne ve babalar yeni ebeveyn olmanın verdiği heyecanla çocuklarının gelişimi ve eğitimi konusunda daha dikkatli davranmakta, onların gelişimlerini daha yakından takip etmektedirler. ileri yaşlı ebeveynler ise çocuklarına zamanla kazanmış oldukları tecrübe ile yaklaşmaktadır. Her iki ebeveyn türü de çocuğun dikkatini ve dürtülerini kontrol etmesine, olumlu duygular geliştirebilmesine ve akademik gelişimlerine destek olmaktadır. Dolayısıyla anne ve babanın yaşının, çocukların öz düzenleme becerileri ve ilkokula hazırbulunuşlukları üzerinde bir etkiye sahip olmadığı düşünülmektedir.

Araştırma sonucunda erken çocukluk dönemi çocuklarının öz düzenleme beceri düzeylerinin ve ilkokula hazırbulunuşluk düzeylerinin annenin ve babanın öğrenim durumu değişkenlerinden etkilendiği sonucuna ulaşılmıştır. Elde edilen bulgulara göre anneleri ile ilkokul ve ortaokul mezunu olan çocukların öz düzenleme beceri düzeyleri ve ilkokula hazırbulunuşluk düzeylerinin, annesi ile babası lise ve üniversite mezunu çocuklara göre daha düşük olduğu sonucuna da ulaşılmıştır. Bununla birlikte anneleri ve babaları lise mezunu çocukların öz düzenleme genel beceri düzeyleri ile ilkokula hazırbulunuşluk düzeylerinin, anneleri ve babaları üniversite mezunu çocuklara göre daha düşük; anneleri ve babaları üniversite mezunu çocukların öz düzenleme genel beceri düzeyleri ile ilkokula hazırbulunuşluk düzeylerinin, anneleri ve babaları lise mezunu çocuklara göre daha yüksek olduğu sonucuna ulaşılmıştır. Bu sonuçlara göre çocukların anne ve babalarının öğrenim durumları yükseldikçe çocuklarının öz düzenleme beceri düzeylerinin ve ilkokula hazırbulunuşluklarının da genel olarak arttığı söylenebilir. Annenin öğrenim düzeyi yükseldikçe, çocukların genel beceri düzeylerinden aldıkları puan ortalamalarının yüksek olması; öğrenim düzeyi yüksek annelerin çocuklarının akademik ve sosyal-duygusal gelişimleriyle daha yakından ilgilendiklerini düşün-dürmektedir. Erkan (2011)'ın bulgusu araştırma bulgusunu destekler niteliktedir. Erkan (2011), farklı sosyo-ekonomik düzeydeki ilköğretim birinci sınıf öğrencilerinin okula hazırbulunuşluklarını incelediği araştırmasında, annesi lise ve yükseköğrenimli olan çocukların okula hazırbulunuşluk düzeylerinin, annesi düşük öğrenimli olanlara göre daha yüksek olduğu sonucuna ulaşmıştır. Ertürk Kara ve Gönen (2015) ise okulöncesi dönemdeki çocukların öz düzenleme becerisini çeşitli değişkenler açısından inceledikleri araştırmalarında 48-72 aylık çocukların öz düzenleme becerisi dikkat/dürtü puanları arasında anne öğrenim durumuna göre anlamlı bir fark bulurken, olumlu duygu puanları arasında bu farkın anlamlı olmadığını bulmuşlardır. Araştırma sonucunda öğrenim durumu yüksek olan annelerin çocuklarının dikkat dürtü puanlarının diğer çocuklara kıyasla daha yüksek olduğu sonucuna ulaşılmıştır. Günümüzde babaların da en az anneler kadar çocuk gelişimi ve eğitimi konularında ilgili ve bilinçli oldukları düşünüldüğünde, öğrenim düzeyi yüksek babaların öğrenim düzeyi düşük babalara göre çocuklarının akademik gelişimleriyle daha yakından ilgilendikleri, çocukların okuma yazma beceri gelişimine daha fazla destek oldukları düşünülebilir. Akçum, (2005) 5-6 yaş çocuklarının yaratıcılık ve öğrenime hazır oluş düzeylerine okul öncesi eğitimin etkisini incelediği araştırmasında, çocukların öğrenime hazır oluş düzeylerinde baba öğrenim durumu okuma olgunluğu ve genel olgunluk boyutlarında etkili olduğu, sayı olgunluğu boyutunda ise etkili olmadığını saptamıştır. Öğrenim düzeyi yüksek ebeveynlerin çocukları ile daha kaliteli zaman geçireceği, çocuklarına dikkat ve dürtülerin kontrol edilmesi ve olumlu duygular geliştirilebilmesi ile akademik becerilerin geliştirilmesi konularında daha profesyonel destek olabileceği değerlendirilmektedir. Bu nedenle anne ve babaların öğrenim durumları yükseldikçe çocuklarının öz düzenleme becerilerinin ve ilkokula hazırbulunuşluklarının da aynı doğrultuda artacağı düşünülmektedir.

Araştırma sonucunda annenin ve babanın çalışma durumunun çocukların öz düzenleme beceri düzeyleri ile ilkokula hazırbulunuşluk düzeylerine etki etmediği sonucuna ulaşılmıştır. Öztabak (2017), okul öncesi dönem çocuklarının öz düzenleme becerileri ile anne-baba tutumları arasındaki ilişkiyi incelediği araştırmasında, örneklem grubundaki çocukların öz düzenleme becerilerinin anne veya babaların mesleğinden anlamlı düzeyde etkilenmediği sonucuna ulaşmıştır. Çalışan anne ve babalar bir işe sahip olduklarından zaman yönetimi konusunda daha profesyonel olacakları için çocukları ile daha kaliteli zaman geçirerek onların dikkat-dürtü kontrolü ve olumlu duygu gelişimlerine ve ilkokula hazırbulunuşluklarına daha fazla katkıda bulunabilir. Bununla birlikte çalışmayan anne ve babalar ise çalışan anne ve babalara göre çocukları ile daha fazla ilgilenme fırsatı bulacaklardır. Dolayısıyla ebeveynlerin çalışma durumlarının, çocukların öz düzenleme becerileri ve ilkokula hazırbulunuşlukları üzerinde bir etkisinin olmadığı düşünülmektedir.

Okul öncesi öz düzenleme ölçeği alt boyutlarına ait puanlar ile ilkokula hazırbulunuşluk ölçeği alt boyutlarına ait puanlar arasında ilişki olup olmadığı incelendiğinde çocukların dikkat-dürtü kontrolü puanları ile okuma hazırlığı puanları arasında pozitif yönde yüksek düzeyde; sayı hazırlığı puanları ile arasında pozitif yönde orta düzeyde ve kopya etme beceri puanları ile arasında pozitif yönde düşük düzeyde anlamlı bir ilişki olduğu tespit edilmiştir. Buna göre dikkat-dürtü kontrolü düzeyi yüksek olan çocukların, okuma hazırlığı düzeylerinin yüksek; sayı hazırlığı düzeylerinin orta; kopya etme beceri düzeylerinin ise düşük seviyede olduğu söylenebilir. Bir başka deyişle, erken çocukluk dönemi çocuklarının dikkat-dürtü kontrolü düzeyleri arttıkça, okuma ve sayı becerilerini öğrenmeye, kopya etme becerilerini geliştirmeye daha hazır oldukları söylenebilir. Bununla birlikte çocukların olumlu duygu puanları ile okuma hazırlığı puanları arasında pozitif yönde orta düzeyde; sayı hazırlığı puanları ile arasında da pozitif yönde

|Kastamonu Eğitim Dergisi, 2020, Vol. 28, No. 5 | 
düşük düzeyde anlamlı bir ilişki olduğu tespit edilmiştir. Buna karşın olumlu duygu puanları ile kopya etme beceri puanları ile arasında anlamlı bir ilişki görülmemektedir. Buna göre olumlu duygu düzeyi yüksek olan çocukların, okuma hazırlığı düzeylerinin orta; sayı hazırlığı düzeylerinin düşük seviyede olduğu söylenebilir. Bir başka deyişle, erken çocukluk dönemi çocuklarının olumlu duygu düzeyleri arttıkça, okuma ve sayı becerilerini öğrenmeye daha hazır oldukları söylenebilir. Bunun yanında çocukların kopya etme becerilerinin olumlu duygu düzeylerinden etkilenmediği söylenebilir.

Metropolitan ilkokula hazırbulunuşluk ölçeği toplam puanlarının okul öncesi öz düzenleme ölçeği alt boyutları puanları ile arasında ilişki olup olmadığı incelendiğinde, erken çocukluk dönemi çocuklarının dikkat-dürtü kontrolü alt boyutu puanları ile ilkokula hazırbulunuşluk puanları arasında yüksek düzeyde, olumlu duygu alt boyutu ile ilkokula hazırbulunuşluk puanları arasında ise orta düzeyde pozitif yönlü anlamlı bir ilişki olduğu tespit edilmiştir. Buna göre, dikkat-dürtü kontrolü düzeyi yüksek çocukların ilkokula hazırbulunuşluk düzeylerinin yüksek; olumlu duygu düzeylerinin ise orta seviyede olduğu söylenebilir. Bir başka deyişle, erken çocukluk dönemi çocuklarının dikkat ve dürtülerini daha iyi kontrol edebildiği ve olumlu duygular geliştirebildiği ölçüde ilkokula hazırbulunuşluklarının arttığı söylenebilir. Çocuğun hem akademik yönden hem de sosyal yönden okula hazır olmasında dikkat-dürtü kontrolü ve olumlu duygu becerileri etkilidir. Ancak dikkat ve dürtü kontrolü becerilerinin olumlu duygu becerisine göre daha önemli bir konumda olduğu düşünülmektedir. Çünkü dikkat ve dürtülerini kontrol edebilen çocukların, akademik sorumlulukları zorlanmadan yerine getireceği değerlendirilmektedir. Ayrıca dikkatini kontrol ederek başarı duygusu-nu elde ettikçe çocuğun kendine güveni artar. Kendine güveni artan çocukların ise olumlu duygular geliştirebileceği düşünülmektedir.

Okul öncesi öz düzenleme ölçeği toplam puanlarının ilkokula hazırbulunuşluk ölçeği alt boyutları puanları ile arasın-da ilişki olup olmadı̆̆ı incelendiğinde, çocukların öz düzenleme genel puanları ile okuma hazırlığı alt boyutu puanları arasında yüksek düzeyde, sayı hazırlığı alt boyutu puanları ile arasında orta düzeyde ve kopya etme alt boyutu puanları ile arasında düşük düzeyde pozitif yönlü bir ilişki bulunduğu tespit edilmiştir. Buna göre öz düzenleme beceri düzeyi yüksek olan çocukların, okuma hazırlığı düzeylerinin yüksek; sayı hazırlığı düzeylerinin orta; kopya etme beceri düzeylerinin ise düşük seviyede olduğu söylenebilir. Bir başka deyişle, erken çocukluk dönemi çocuklarının öz düzenleme beceri düzeyleri arttıkça, okuma ve sayı becerilerini öğrenmeye, kopya etme becerilerini geliştirmeye daha hazır oldukları söylenebilir. Dikkat ve dürtülerini kontrol edebilen çocuklar okumaya daha iyi odaklanabilmekte ve sayıları öğrenmeye daha hazır hale gelebilmektedir. Öz düzenleme beceri düzeyi yüksek çocukların, okuma hazırlığı düzeylerinin yüksek, sayı hazırlığı düzeylerinin orta seviyede olmasının, matematik becerilerinin okuma yazmaya hazırlık becerilerinden daha üst düzey bilişsel becerilerden biri olmasından kaynaklandığı düşünülmektedir. Kopya etme becerileri ise görsel algı becerilerini içerir. Görsel algı becerisi gelişmemiş çocukların ilkokula başlamasıyla birlikte hecelemede, okuma yazmanın gelişiminde, matematik becerilerinin kazanılmasında sınıf etkinliklerine ve oyuna katılmada problemler görülebilmektedir (Ercan vd., 2016; 321). Bu nedenle öz düzenleme becerisi yüksek çocukların kopya etme becerilerinin düşük seviyede olmasının, kopya etme becerilerinin, okuma ve sayı hazırlığı becerilerinden daha üst düzey bilişsel becerilerden biri olmasından kaynaklandığı düşünülmektedir.

\section{SONUÇ VE ÖNERILER}

Araştırma sonucunda öz düzenleme becerilerinin, çocukların ilkokula hazırbulunuşlukları üzerinde anlamlı bir etkiye sahip olduğu belirlenmiştir. Bununla birlikte anne babaların, çocuk eğitimi üzerindeki etkisi de göz önüne alındığında öz düzenleme becerileri gelişimi ve dolayısıyla çocukların ilkokula hazırbulunuşluklarının daha iyi düzeyde olabilmesi için aile katılım ve eğitim etkinliklerinde öz düzenleme konusu ele alınabilir. Ayrıca ebeveynlere çocukları ile birlikte evde yapılabilecek etkinliklerin okula hazır oluştaki yeri konusunda bilgilenmelerini sağlayacak aile eğitim programları hazırlanabilir. Bu çalışma Muğla ilinde okul öncesi eğitim kurumuna devam eden 255 çocuk ile gerçekleştirilmiştir. Daha sonraki çalışmalar daha geniş ve farklı sosyo-ekonomik bölgelerde yer alan çalışma gruplarıyla gerçekleştirilebilir. Öz düzenleme becerilerinin çocuğun ilkokula hazır bulunuşluğuna etkisi göz önüne alındığında sonraki çalışmalar çocukların ilkokula hazırbulunuşluklarını etkileyebilecek farklı değişkenlerle birlikte incelenerek yürütülebilir. Okul öncesi alanında çalışan araştırmacılar, çocukların öz düzenlemelerinin gelişim sürecinin izlenebilmesi için boylamsal çalışmalar planlayabilirler.

\section{KAYNAKÇA}

Akcay, A., \& Altun, A. (2019). Farklı kısa süreli bellek uzamlarına sahip öğrencilerin farklı dikkat tasarımına sahip öğrenme ortamlarındaki göz hareketlerinin incelenmesi. Eğitim Teknolojisi Kuram ve Uygulama, 9(2) , 588-614 . doi: 10.17943/etku.568192

Somyürek, S., \& Coşkun, B.K. (2013). Digital competence: Is it an innate talent of the new generation or an ability that must be developed?. British Journal of Educational Technology, 44(5), E163-E166. doi: 10.1111/bjet.12044

Akar, I., \& Ahi, B. (2020). How is the environment in the mind of a gifted elementary school student? A phenomenology study. International Electronic Journal of Environmental Education, 10(1), 85-97.

Fraenkel, W., Wallen, N.E., \& Hyun, H.H. (2011). How to design and evaluate research in education (8th Edition). New York: McGraw-Hill Education

Akawi, R.L. (2011). An investigation into the relationship between self-regulation skills and academic readiness in head start children. Doctoral Thesis, A Dissertation Submitted to the University at Albany, State University of New York in Partial Fulfillment of the Requirements for the Degree of Doctor of Philosophy, New York. 
Akçum, E. (2005). 5-6 yaş çocuklarının yaratıcılık ve öğrenime hazır oluş düzeylerine okul öncesi eğitimin etkisinin incelenmesi. Yüksek Lisans Tezi. Selçuk Üniversitesi, Sosyal Bilimler Enstitüsü, Konya.

Aydın, F. \& Ulutaş, İ. (2017). Okul öncesi çocuklarda öz düzenleme becerilerinin gelişimi. Aksaray Üniversitesi Sosyal Bilimler Enstitüsü Dergisi, 2, 36-45.

Aydın, F. (2018). Okul öncesi dönem çocuklarının öz düzenleme becerilerinin ve duygusal zekalarının incelenmesi. Yüksek Lisans Tezi. Gazi Üniversitesi Eğitim Bilimleri Enstitüsü, Ankara.

Bayındır, D. \& Ural, O. (2016). Öz düzenleme becerileri ölçeğinin geliştirilmesi. International Online Journal of Educational Sciences, 8, 119-132

Blair C. \& Raver C.C. (2015). School readiness and self regulation: A developmental psychobiological approach. HHS Public Access. $66,711-731$.

Blair, C. \& Razza, R.P. (2007). Relating effortful control, executive function, and false belief understanding to emerging math and literacy ability in kindergarten. Child Development, 78, 647-663.

Boyd, J., Barnett, S.W., Bodrova, E., Leong, D.J., ve Gomby, D. (2005). Promoting children's social and emotional development through preschool education. National Institute for Early Education Research, 1-21.

Bronson, MB (2000). Self- regulation in early childhood: Nature and nurture. New York: Guilford Press

Büyüköztürk, Ş. (2013). Sosyal bilimler için veri analizi el kitabı. Ankara: Pegem Akademi

Büyüköztürk, Ş., Çakmak, E.K., Akgün, Ö.E., Karadeniz, Ş., \& Demirel, F. (2013). Bilimsel araştırma yöntemleri. Ankara: Pegem Akademi Yayıncılık

Can Aran, Ö (2015). Öz düzenleme ve çalışma becerileri arasındaki ilişki. Pegem Eğitim ve Öğretim Dergisi, 5, $207-220$.

Carlson, S.M. \& Wang, T.S. (2007). Inhibitory control and emotion regulation in preschool children. Cognitive Development, 22, 489-510.

Eisenberg, N. \&Spinrad, T.L. (2004). Emotion-related regulation: Sharpening the definition. Child Development, 75, $334-339$.

Eisenberg, N., Eggum, N.D, Sallquist, J \& Edwards, A (2010). Relations of self-regulatory control capasities to maladjustment, social competence, and emotionality. R. H. Hoyle (Ed.), Handbook of Personality and Self-Regulation (s. 21-46). United King-dom: Wiley-Blackwell Publishing.

Eisenberg, N., Smith, C.L. \& Spinrad, T.L. (2011). Effortful control: relations with emotion regulation, adjustment, and socialization in Childhood. Baumeister R. F. \& Vohs K.D. (Ed.), Handbook of self-regulation: Research, theory, and applications (s. 259-282). New York: Guilford Press

Eisenberg, N., Valiente, C., \& Eggum, N.D., (2010). Self-regulation and school readiness. Early Education and Development 21, 681698

Eke, K. (2017). Okul öncesi dönemdeki çocukların öz düzenleme becerileri ile anne-baba tutumları arasındaki ilişkinin incelenmesi. Uluslararası Avrasya Sosyal Bilimler Dergisi. 28, 293-307

Ercan, Z., Ahmetoğlu E. \& Aral N. (2016). Görsel algı eğitiminin beş-altı yaş grubundaki çocukların görsel-motor bütünlük becerilerine etkisi, International Journal Of Social Science. 48, 319-332.

Erkan, S. (2011). Farklı sosyoekonomik düzeydeki ilköğretim birinci sınıf öğrencilerin okula hazır bulunuşluklarının incelen-mesi, Hacettepe Üniversitesi Eğitim Fakültesi Dergisi 40, 186-197

Ertürk H.G. (2013). Öğretmen çocuk etkileşiminin niteliği ile çocukların öz düzenleme becerisi arasındaki ilişkinin incelenmesi. Doktora Tezi, Hacettepe Üniversitesi, Sosyal Bilimler Enstitüsü, Ankara.

Ertürk Kara H.G. \& Gönen M. (2015). Okul öncesi dönemdeki çocukların öz düzenleme becerisinin çeşitli değişkenler açısından Incelenmesi, Eğitimde Kuram ve Uygulama Dergisi 11, 1224-1239.

Fındık Tanrıbuyurdu, E. (2012). Okul Öncesi öz düzenleme ölçeği geçerlik ve güvenirlik çalışması. Yüksek Lisans Tezi, Hacettepe Üniversitesi, Sosyal Bilimler Enstitüsü, Ankara.

Garnefski, N, Kraaij, V \& Spinhoven, P (2001). Negative life events, cognitive emotion regulation and emotional problems. Personality and Individual Differences, 30, 1311-1327.

Grolnick, W.S. \& Farkas, M. (2002). Parenting and the development of self-regulation. In M.H. Bornstein (Ed.), Handbook of parenting; Practical issues in parenting (s. 89-110), Hillsdale, NJ: Erlbaum.

Izard, C., Fine, S., Schultz, D., Mostow, A., Ackerman, B. \& Youngstrom, E. (2001). Emotion knowledge as a predictor of social behavior and academic competence in children at risk. Psychological Science, 12, 18-23.

Karasar, N. (2017). Bilimsel araştırma yöntemi. Ankara: Nobel

Keleş, S. (2014). Kültürel-tarihsel kuram bağlamında hazırlanan eğitim programının 48-60 aylık çocukların öz düzenleme gelişimi üzerine etkisinin incelenmesi. Doktora Tezi. Gazi Üniversitesi Eğitim Bilimleri Enstitüsü, Ankara.

Koçyiğit, S. (2009). İlköğretim birinci sınıf öğretmenlerinin ve ebeveynlerin görüşleri ışığında okula hazırbulunuşluk olgusu ve okul öncesi eğitime ilişkin sonuçları. Doktora Tezi. Selçuk Üniversitesi Sosyal Bilimler Enstitüsü, Konya

| Kastamonu Eğitim Dergisi, 2020, Vol. 28, No. 5| 
Magdalena, S.M. (2014). The effects of parental influences and school readiness of the child. Procedia - Social and Behavioral Sciences, $127,733-737$

Mason, J.M. \& Sinha, S. (1992). "Emerging literacy in the early childhood years: Applying a vygotskian model of learning and development." Andrew W. Mellon Foundation, New York.

Molnar, E.D. (2016). The level of self-regulation amongst 5-7 years old Hungarian children. Sözel Bildiri Multidisciplinary Aca-demic Conference. Prag, Çek Cumhuriyeti

Montroy, J.J., Bowles, P.P., Skibbe, L.L., \& Foster, T.D. (2014). Social skills and problem behaviors as mediators of the relationship between behavioral self-regulation and academic achievement, Early Childhood Research Quarterly, 29, $298-309$.

Ochsner, K.N. \& Gross, J.J. (2005). The cognitive control of emotion. Trends in Cognitive Sciences, 9, $242-249$.

Oktay, A. (1983). Okul olgunluğu. İstanbul: İstanbul Üniversitesi Edebiyat Fakültesi Yayınları.

Oktay, A. (2013). Illköğretime hazır oluş ve hazır oluşu etkileyen temel faktörler. A. Oktay, (Ed.), illköğretime Hazırlık ve ilköğretim Programları içinde (s. 21-34). Ankara: Pegem Akademi Yayıncılık.

Öner, N. (2008). Türkiye'de kullanılan psikolojik testlerden örnekler: Bir başvuru kaynağı. İstanbul: Boğaziçi Üniversitesi Yayın-ları

Öztabak, M.E. (2017). Okul öncesi dönem çocuklarının öz düzenleme becerileri ile anne baba tutumları arasındaki ilişkinin incelenmesi. Yüksek Lisans Tezi. Karabük Üniversitesi Sağlık Bilimleri Enstitüsü, Karabük.

Riva, S.D.L. \& Ryan T.G. (2015). Effect of self-regulating behaviour on young children's academic success, International Journal of Early Childhood Special Education (INT-JECSE), 7, 69-96.

Sektnan, M., McClelland, M., Acock, A., \& Morrison, F. (2010). Relations between early family risk, children's behavioral regulation and academic achievement. Early Childhood Research Quarterly, 25, 464-479.

Smith Donald, R., Raver, C.C., Hayes, T, \& Richardson, B. (2007). Preliminary constructand concurrent validity of preschool selfregulation sssesment (PSRA) for field-based research. Early Childhood Research Quarterly, 22, 173-187.

Şahin, G., \& Arı, R. (2016). Okul öncesi çocukların yürütücü işlevleri ve duygu düzenleme becerileri arasındaki ilişkinin incelenmesi. Uluslararası Eğitim Bilimleri Dergisi. 6, 1-9.

Tilbe, E. (2015). Okul öncesi çocuklarında davranış düzenleme becerisi ve ebeveyn tutumu ve davranış sorunları arasındaki ilişkinin incelenmesi. Yüksek Lisans Tezi, Bahçeşehir Üniversitesi, Sosyal Bilimler Enstitüsü, İstanbul.

Torres, M.M. (2011). Understanding self-regulation, links to school readiness, and implications for intervening with high-risk children. Doctorate Thesis, Pennsylvania State University, USA.

Tozduman Yaralı, K. \& Güngör Aytar, F.A. (2016). Okul öncesi dönem çocuklarının davranışlarının öz düzenleme becerileri yönünden incelenmesi. Mersin Üniversitesi Eğitim Fakültesi Dergisi, 13, 856 - 870.

Vohs, K.D. \& Baumeister, R.F. (2011), Handbook of self-regulation: Research, theory, and applications (s. 263-283). New York: Guilford Press.

Willis, E. \& Laura, H.D. (2013). Contemplative practices in early childhood: implications for self-regulation skills and school readiness. Early child development and care. 4, 487-499

Yapıcı, M. (2004). İlköğretim I. sınıfa başlayan öğrencilerin hazırbulunuşluk düzeyi. Uluslararası İnsan Bilimleri Dergisi, 1, 3-4.

Yıldız, T, Ertürk Kara, H.G., Fındık Tanrıbuyurdu, E., \& Gönen, M. (2014). Öz düzenleme becerilerinin öğretmen çocuk etkileşiminin niteliğine göre incelenmesi. TED Eğitim ve Bilim Dergisi, 176, 329-338.

Zimmerman, B.J. (2000). Attainment of self-regulation: A social cognitive perspective. M. Boekaerts, P.R. Pintrich ve M. Seidner (Ed.). Handbook Of Self-Regulation (s. 13-39). San Diego, CA: Academic Press. 